\title{
A Study of Generation Z Viewing Habits in Context of Uses and Gratification Theory: The Protector Netflix Series Case
}

\author{
Ayten A. ${ }^{1}$ \\ Bulat S.2 \\ İnceismail $E^{3}$
}

\author{
1 Adem AYTEN, İstanbul Aydın University, (Turkey) \\ e-mail: ademayten@aydin.edu.tr \\ 2 Sema BULAT, İstanbul Aydın University, (Turkey) \\ e-mail: semabulat@aydin.edu.tr \\ 3 Elif îNCEISMAiL, İstanbul Aydın University, (Turkey) \\ e-mail: elifinceismail@aydin.edu.tr
}

\begin{abstract}
In recent years online broadcasting has accelerated through online broadcasting platform Netflix. Therefore the generation $Z$ that defined as digital natives has a differenciaty viewing habit. It is defined as binge watch and binge racer by Netflix. The users watch episodes of a Netflix series at one time nonstop. The aim of the research is to find out the factors carry out generation Z's online viewing habits, in the context of uses and gratification theory. To conduct the research The Protector, the first Turkish series of Netflix, is choosen as a case and survey is done with The Protector's watchers.
\end{abstract}

Keywords: Binge Watch, Binge Racer, The Protector, Uses and Gratification Theory

\section{Introduction}

Traditional viewing habits have begun to evolve with the development of technology. Particularly, the generation $Z$, that is born into new communication technologies and called as digital natives, decides themselves to watch what, where, when and how long. Television's fixed broadcasting timetable and its viewing habits are not prevailing for the generation $Z$, that does not recognize time and space boundaries. With the emergence of online broadcasting platforms, generation $Z$ has started use these online broadcasting platforms to adopt new viewing habits. The online platform Netflix defined those new viewing habits as bing watch. Also the Netflix defined these new watchers as binge watcher and binge racer due to their viewing acts. The research is focusing on factors that orients viewers towards to new viewing habits in contexts of binge watch, binge watcher and binge racer concepts.

Human life is averagely 80 years and during this period, it goes through 4 periodic processes. These periodic processes are childhood, youth, adulthood and old age. In this case, it is possible to say that a new generation is coming up about every 20 years. (Twenge, 2009: 10-12) Five generations have been defined in the last centure; i) builders: born before 1940, ii) baby boomers: born between 1940 and 1960, iii) Gen X: born between 1960 and 1980, iv) Gen Y: born between 1980 and 2000, v) Gen Z: born in 2000 and beyond. Some researchers consider the beginning of the Gen $Z$ as 1995 and beyond (Seymen, 2017: 472). Due to the speed of change in technology, the differentiation of generations has also accelerated. Therefore, Gen Z is differentiating faster than its predecessors.

To consider on the basic features that distinguish the generation $Z$ from its predecessors, the following concepts emerge (Stillman \& Stillman, 2017: 7-8). 
Phygital (physical plus digital): 'Phygital' is a term used to describe the interaction between a physical and digital space. As digital natives they have a combined physical and virtual world perception.

Hyper - Custom: Hyper-personalization takes personalized marketing a step further by leveraging artificial intelligence $(\mathrm{Al})$ and real-time data to deliver more relevant content, product, and service information to each user (Lebo, 2019).

Realist: They have a very utilitarian mentality in preparing for the future and making plans. They have a realistic and planned view of life.

FOMO: A form of social anxiety - a compulsive concern that one might miss an opportunity or satisfying event, often aroused by posts seen on social media websites.

Weconomists: They are willing to support the "we" economy instead of me, which emphasizes the benefit of society (they use Airbnb, Uber and etc that are part of gig economy).

DIY (Do It Yourself): As they grow up with do-it-yourself videos, they think they can do almost anything on their own.

Driven: Gen $Z$ is one driven generation. Gen $Z$ is ready and hungry to roll up their sleeves. They will be more competitive as well as privaten than previous generations.

Considering these features, Gen Z, which does not recognize the world before the digital revolution, takes decisions much faster, tries to catch up with everything and gets distracted quickly. The above-mentioned characteristics of Gen Z influences their daily life, their perception of the world. For this reason, past viewing habits are also undergoing some changes. Many researches point out that Gen Z prefers to be online and constantly interactive. It is seen that the main medium that determines media usage habits of the Gen $Z$ is the internet. In this context, it is thought that broadcasting of new online series is according to the media consumption habits of the Gen $Z$.

Rapidly developing technology and the Internet are changing and shaping many of our habits (Poe, 2014:16). Our viewing habits have also changed in recent years. The action of shooting and sharing videos starting with social media has caused audience to move away from traditional media tools that require longer-term attention. Realizing that individuals spend more time on the internet, the broadcasters started the online casting age switching to the internet environment. Internationally Netflix and locally BluTV and PuhuTV are the first examples of online castings. Initially, these platforms have been casting contents produced for television and cinema, and then started to produce their original content to cast online to respond to the demands of the online consumer. Netflix pioneered the production of original content for online cast. One of the outputs of online broadcasting is to present one season of the series to the consumer in one go. On online platforms unlike traditional media, consumers can watch any episode of the series at anytime, anywhere, without waiting. (Yengin \& Kınay, 2015: 221) The well known American online brodcasting company Netflix defined this new type of viewing as binge watch. (Yengin \& Kınay, 2015: 222) Binge watch refers to watch many or all episodes of (a TV series) in rapid succession. And the person who binge watches is binge watcher. The concept of binge racer, introduced by Netflix in 2017, defines the viewers who show the behavior of watching one season of a series in one sitting (within 24 hours) (Krstic, 2018).

Within the scope of the study, in order to explain the online viewing habits of Gen Z the uses and gratification theory that explains audience satisfaction and how audience prefers a mass media was used.

\section{The Uses and Gratification Theory}

Uses and gratifications theory asserts that people use media to gratify specific wants and needs. Unlike many media theories that view media users as passive, uses and gratifications sees users as active agents who have control over their media consumption. 
Uses and gratifications was first introduced in the 1940s as scholars began to study why people choose to consume various forms of media. For the next few decades, uses and gratifications research mostly focused on the gratifications media users sought. Then, in the 1970s, researchers turned their attention to the outcomes of media use and the social and psychological needs that media gratified. Today, the theory is often credited to Jay Blumler and Elihu Katz's work in 1974. As media technologies continue to proliferate, research on uses and gratifications theory is more important than ever for understanding people's motivations for choosing media and the gratifications they get out of it.

Uses and gratifications theory relies on two principles about media users. First, it characterizes media users as active in their selection of the media they consume. From this perspective, people don't use media passively. They are engaged and motivated in their media selections. Second, people are aware of their reasons for selecting different media options. They rely on their knowledge of their motivations to make media choices that will help them meet their specific wants and needs (Güngör, 2013: 122).

On the basis of those principles, uses and gratifications goes on to outline: (Tokgöz, 2015:

- Media use is goal-directed. People are motivated to consume media.

- Media is selected based on the expectation that it will satisfy specific needs and desires.

- Media influence on behavior is filtered through social and psychological factors. Thus, personality and social context impact the media choices one makes and one's interpretation of media messages.

- Media are in competition with other forms of communication for an individual's attention. For example, an individual may choose to have an in-person conversation about an issue instead of watching a documentary about the issue.

- People are usually in control of media and therefore are not particularly influenced by it.

Taken together, uses and gratifications theory stresses the power of the individual over the power of the media. Individual differences mediate the relationship between media and their effects. This results in media effects being driven as much by the media user as by the media content itself. So, even if people take in the same media message, each individual will not be impacted by the message in the same way.

To Blumler and Katz's opinion audiences choose and use a media for the following 4 Media Purposes or Uses and Gratifications: routine (escapism).

Diversion or Entertainment: people use media to get away from everyday problems and

Personal Relationships: people use media as a substitute for real emotional and interpersonal interaction. It is frequent that people watch a soap opera to live emotions they should have typically experienced in their real family life.

Personal Identity: people find themselves reflected in texts and TV programs and they also learn behaviors and values from media.

Surveillance: people use the media to satisfy their need for information. This is typical for people watching weather reports, financial and business news, etc.

Recently, with the coming of new media (internet and video games) the original Blulmer and Katz's list has been widely extended. In 2000 Denis McQuail, active in the field of mass communication studies ratified this methodology, slightly modifying the order and the names of the 4 Uses:

- Information

- Personal Identity

- Integration and Social Interaction

- Entertainment. (Uzun,2013: 90-91) 


\section{The Scope and the Methodology of the Research}

As a conclusion of the acceleration of online broadcasting, Gen Z, which is also known as the digital native, has a new type of viewing habits different from the traditional viewing habits. These viewing habits are defined as binge watch and binge racer by Netflix.

The aim of the research is to examine the online viewing habits of generation $Z$ in the context of The Protector series based on the Uses and Gratification Theory. To conduct the research a survey is done.

The universe of the research is young people who are between 18-24 years old watching The Protector. The reason for choosing it is that Generation $Z$ is in this age range. The Protector series is the first Turkish series to be broadcasted on Netflix. And according to Netflix data, it has reached more than 10 million views in the first 4 weeks since December 14, 2018, when the first episode was broadcasted. (www.media.netflix.com) The fact that the series has reached more than 10 million views in a short time makes it possible to research the concepts of binge watch and binge racer.

As mentioned above to conduct the research a survey of 5 factors including closed-ended questions is developed from the context of uses and gratification theory. 4 of the 5 factors are information, personel identity, integration and social entegration and entertainment that modified by McQuail. (Uzun, 2013: 90-91) The fifth factor of the survey is the production factor consists of character, space, script and etc. Likert scale (5-point) is used in the research. 26 questions' survey was responded by in total 385 people who are between 18 and 24 ages.

The problem of the research is "What factors influence on the viewing habits of generation Z?". And in the context of problem of the research are below:

H1: The audience of the series (The Protector) shows the habit of binge watch.

H2: The audience has watched it as binge racer.

H3: There is a positive corelation between information factor and being a binge watcher/racer.

H4: There is a positive corelation between integration and social interaction factor and being a binge watcher/racer.

H5: There is a positive corelation between entertainment factor and being a binge watcher/racer.

H6: There is a positive corelation between personal identity factor and being a binge watcher/racer.

H7: There is a positive corelation between production factor and being a binge watcher/racer.

\section{Factor Analysis}

Factor analysis is a statistical method used to describe variability among observed, correlated variables in terms of a potentially lower number of unobserved variables called factors. For example, it is possible that variations in six observed variables mainly reflect the variations in two unobserved (underlying) variables. Factor analysis searches for such joint variations in response to unobserved latent variables. The observed variables are modelled as linear combinations of the potential factors, plus "error" terms. Factor analysis aims to find independent latent variables. (Büyüköztürk, 2002: 472 - 478).

Table 1 below figures out the results of the factor analysis of the research. And the results points out that there is an internal consistency of the questionnaire

Rotated Component Matrix(a)

\begin{tabular}{|c|c|c|c|c|c|}
\hline & 1 & 2 & 3 & 4 & 5 \\
\hline Information factor 1 & .159 & .154 & .124 & .168 & .654 \\
\hline Information factor 2 & 272 & .245 & .379 & .144 & .508 \\
\hline Information factor 3 & 200 & .171 & .220 & .191 & .587 \\
\hline Personal idendity 1 & .447 & .664 & .097 & .031 & .025 \\
\hline Personal idendity 2 & 370 & .599 & .157 & .062 & .075 \\
\hline
\end{tabular}

DOI NO: 10.7456/ctc_2019_01

(C) İstanbul Aydın University 


\begin{tabular}{|l|l|l|l|l|l|}
\hline Personal idendity 3 & .500 & .511 & .209 & .082 & .093 \\
\hline $\begin{array}{l}\text { Integration and social } \\
\text { interaction 1 }\end{array}$ & .050 & .199 & .781 & .218 & .127 \\
\hline $\begin{array}{l}\text { Integration and social } \\
\text { interaction 2 }\end{array}$ & .512 & .113 & .626 & .102 & .114 \\
\hline $\begin{array}{l}\text { Integration and social } \\
\text { interaction 3 }\end{array}$ & .290 & .143 & .795 & .082 & .071 \\
\hline $\begin{array}{l}\text { Integration and social } \\
\text { interaction 4 }\end{array}$ & .384 & .204 & .662 & .082 & .410 \\
\hline Production 1 & .764 & .204 & .148 & .167 & .098 \\
\hline Production 2 & .758 & .130 & -.019 & .215 & .137 \\
\hline Production 3 & .666 & .110 & .430 & .114 & .229 \\
\hline Production 4 & .608 & .158 & .484 & .071 & .312 \\
\hline Production 5 & .579 & .316 & .211 & .257 & .247 \\
\hline Production 6 & .463 & .301 & .292 & .312 & .145 \\
\hline Production 7 & .537 & .410 & .259 & .348 & .289 \\
\hline Production 8 & .516 & .304 & .384 & .109 & .352 \\
\hline Entertainment 1 & .116 & .127 & .194 & .775 & .125 \\
\hline Entertainment 2 & .194 & .131 & .079 & .809 & .267 \\
\hline Entertainment 3 & .310 & .357 & .175 & .580 & .253 \\
\hline
\end{tabular}

Table 1. The result of Factor Analysis of the research

\section{Reliability Analysis}

Reliability analysis is determined by obtaining the proportion of systematic variation in a scale, which can be done by determining the association between the scores obtained from different administrations of the scale. Thus, if the association in reliability analysis is high, the scale yields consistent results and is therefore reliable.

Cronbach's alpha, a (or coefficient alpha), developed by Lee Cronbach in 1951, measures reliability, or internal consistency. "Reliability" is how well a test measures what it should. For example, a company might give a job satisfaction survey to their employees. High reliability means it measures job satisfaction, while low reliability means it measures something else (or possibly nothing at all).

Cronbach's alpha tests to see if multiple-question Likert scale surveys are reliable. These questions measure latent variables - hidden or unobservable variables like: a person's conscientiousness, neurosis or openness. These are very difficult to measure in real life. Cronbach's alpha will tell you if the test you have designed is accurately measuring the variable of interest.

The formula for Cronbach's alpha is (What does Croanbach's Alpha mean, 2019):

$$
\alpha=\frac{N \bar{c}}{\bar{v}+(N-1) \bar{c}}
$$

Where:

$\mathrm{N}=$ the number of items.

$\overline{\mathrm{c}}=$ average covariance between item-pairs.

$\overline{\mathbf{V}}$ =average variance 


\begin{tabular}{|l|l|}
\hline Cronbach's alpha & Internal consistency \\
\hline$\alpha \geq 0.9$ & Excellent \\
\hline $0.9>\alpha \geq 0.8$ & Good \\
\hline $0.8>\alpha \geq 0.7$ & Acceptable \\
\hline $0.7>\alpha \geq 0.6$ & Questionable \\
\hline $0.6>\alpha \geq 0.5$ & Poor \\
\hline $0.5>\alpha$ & Unacceptable \\
\hline
\end{tabular}

Table 2. Rule of Thumbs for Results (Cronbach's Alpha: Simple Definition, Use and Interpretation, 2019)

In general, a score of more than 0.7 is usually okay. However, some authors suggest higher values of 0.90 to 0.95 . The score of the research is 0,826 . That means the survey has an internal consistency.

\section{Findings}

In context of the research "How often do you watch online series?" question has been asked to the subjects and $89.1 \%$ of 385 subjects between the ages of $18-24$ stated that they watch online series. It can say that about 9/10th ofTurkey's young people who are between 18 - 24 ages shows online viewing habit. To the findings 4 of 10 people perform online watch every day of the week. On the other hand, the rate of those who have the habit of watching online 4-5 days a week is \%26,5.

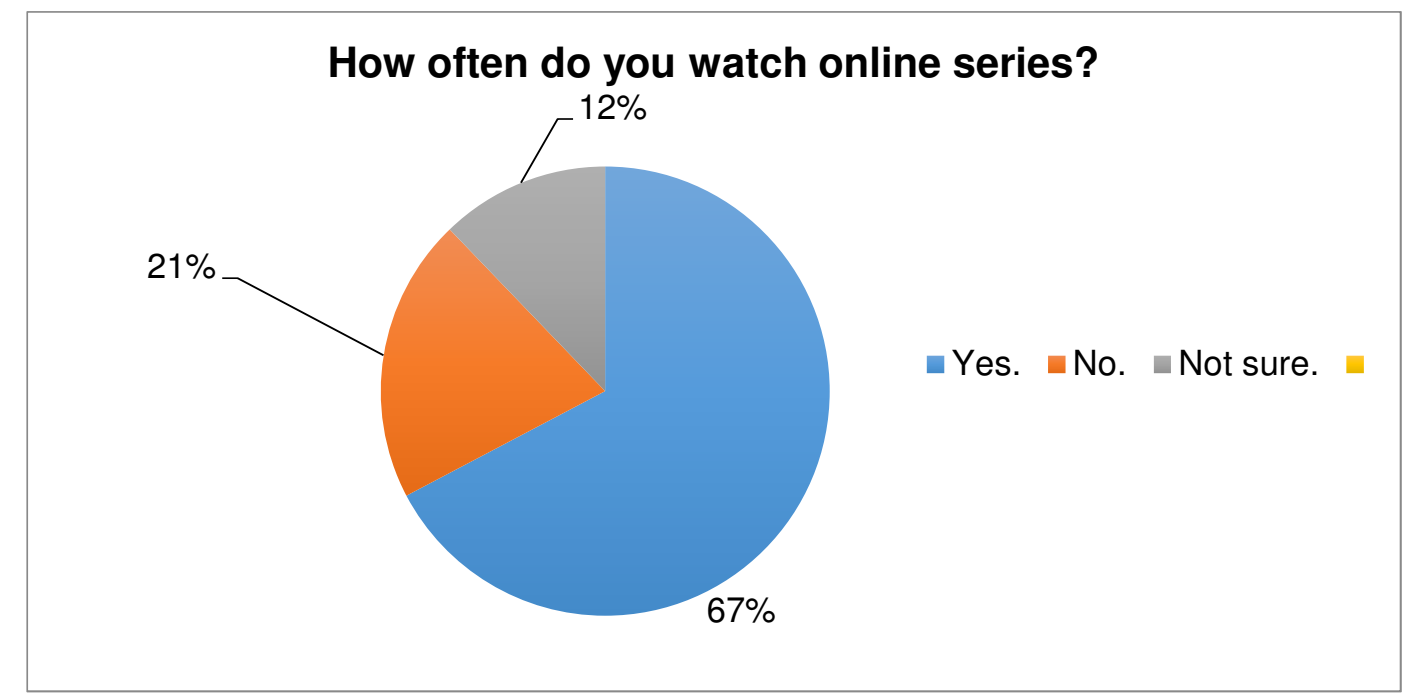

Graph 1: The frequency of online series watching 
A question was asked to find out whether the subjects of the research sample had habit of binge watch. $96.4 \%$ of the subjects stated that previously they watched one after another at least two episodes of a series broadcasted online. To the findings, it can conclude that binge watch is quite common among young people between the ages of 18-24.

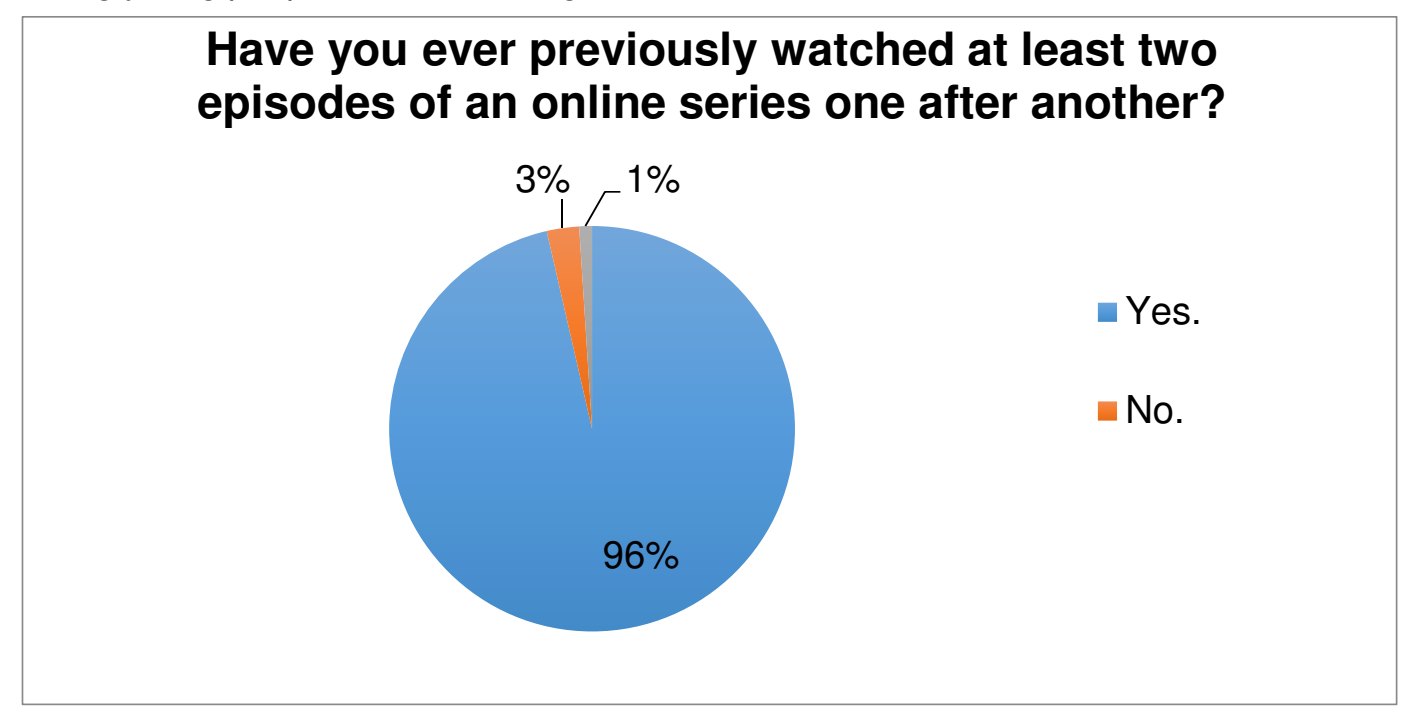

Graph 2: The frequency of watching series online as binge watcher

In order to determine whether the research sample is a binge racer a question is asked. $67.3 \%$ of the subjects stated that they watched a season of a series broadcasted online at one time. In this context, 2/3's of online viewers ages between 18 and 24 in Turkey can be said to show the feature of a binge racer.

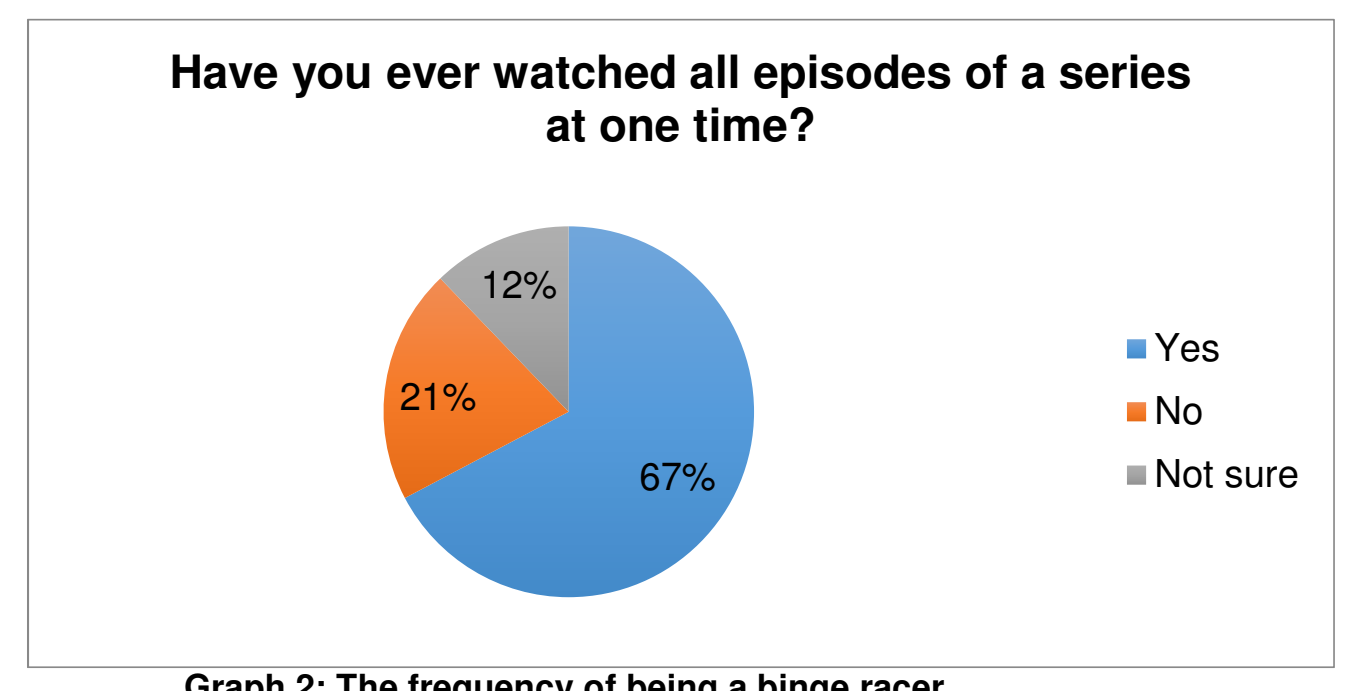

Graph 2: The frequency of being a binge racer

A question is asked as well to determine whether the audience was a binge watcher or a binge racer specifically The Protector Netflix series. The $27.79 \%$ (107 people) of subjects is binge racers, $63.63 \%$ (245 people) of the subjects is binge watchers, and the remaining $(8.57 \%)$ is replied they watched the The Protecter arbitrary (I have watched it when i remembered it, I watched it fast forward and etc.) 


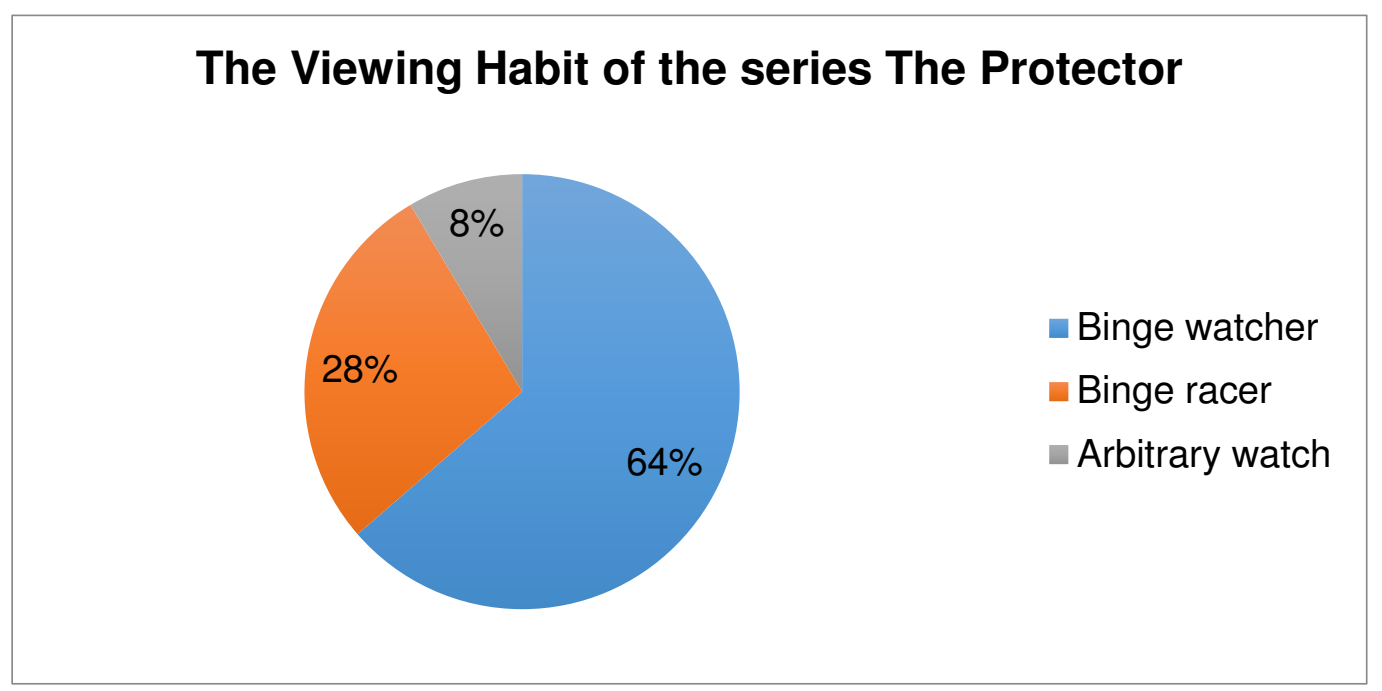

\section{Graph 3: The Viewing Habit of the series The Protector}

$97 \%$ of those who watched the Protector Netflix series as binge racer said they had previously watched another TV series as a binge racer. Similarly, 97\% of those who watched The Protector Netflix series as a binge watcher said they had previously watched another series as a binge watcher. Being a binge watcher and a binge racer is more general and common than a sequence-dependent situation.

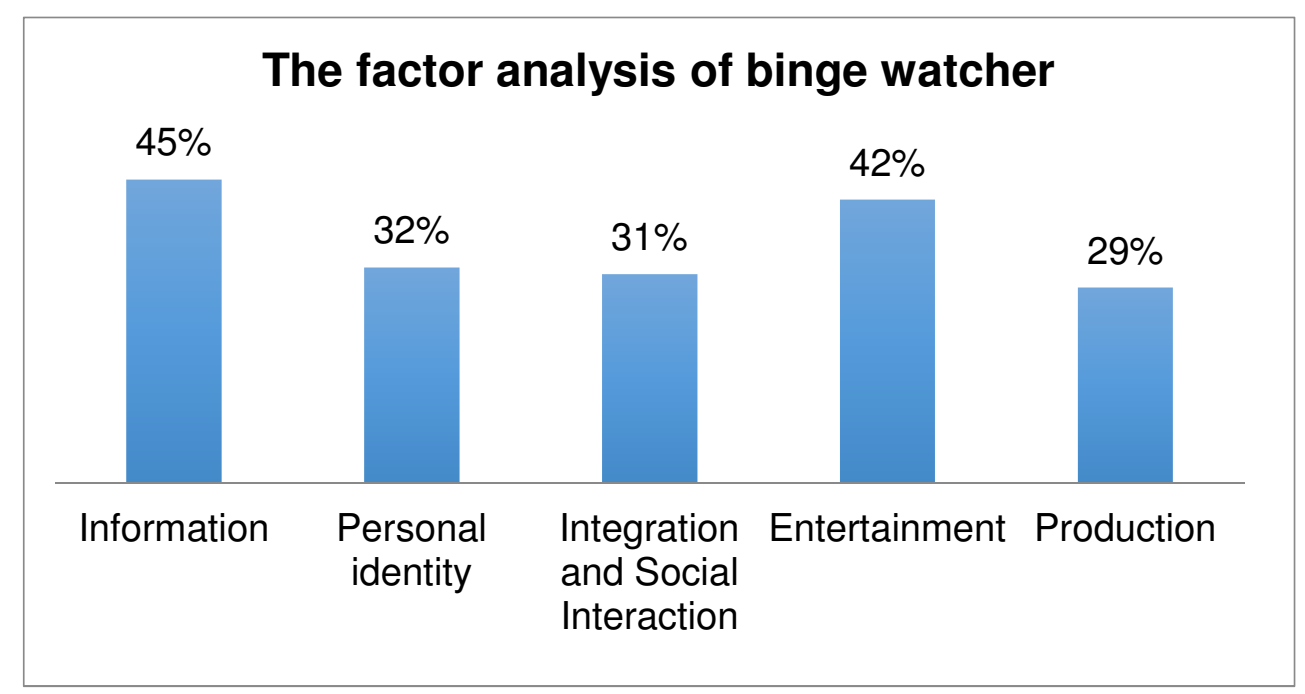

Graph 5: The factor analysis of binge racer in context of The Protector

To the Graph 5, there is a positive correlation with being a binge racer of the Protector Netflix series in particular and information (45\%), integration and social interaction (31\%), personal identity $(32 \%)$, production (29\%) and entertainment $(40 \%)$ factors.

$62 \%$ of binge racers related to information factor stated that they followed the episodes consecutively to avoid of spoilers. It is the highest positive value among the answers of the questions related to the information factor.

$68 \%$ of binge racers related to integration and social interaction factor stated that they prefer to watch the series' episodes in a row cause of it is broadcasted on Netflix an international online platform and will be viewed in other countries. It is the highest value among the answers of the questions related to the integration and social integration factor. 
$60 \%$ of binge racersrelated to personal identity factor stated that they wanted to watch it cause of liking one or more of the cast members (Çağatay Ulusoy, Hazar Ergüçlü, Ayşin Turan, Okan Yalabık, etc.) It is the highest positive value among the answers of the questions related to personal identity factor. $76 \%$ of binge racers related to production factor stated that they liked the script of it and that's why they prefer to watch the series' episodes in a row. It is the highest value among the answers of the questions related to production factor. $71 \%$ of binge racers related to entertainment factor stated that they prefer to watch the episodes of the series one after another to spend free time. It is the highest value among the answers of the questions related to entertainment factor.

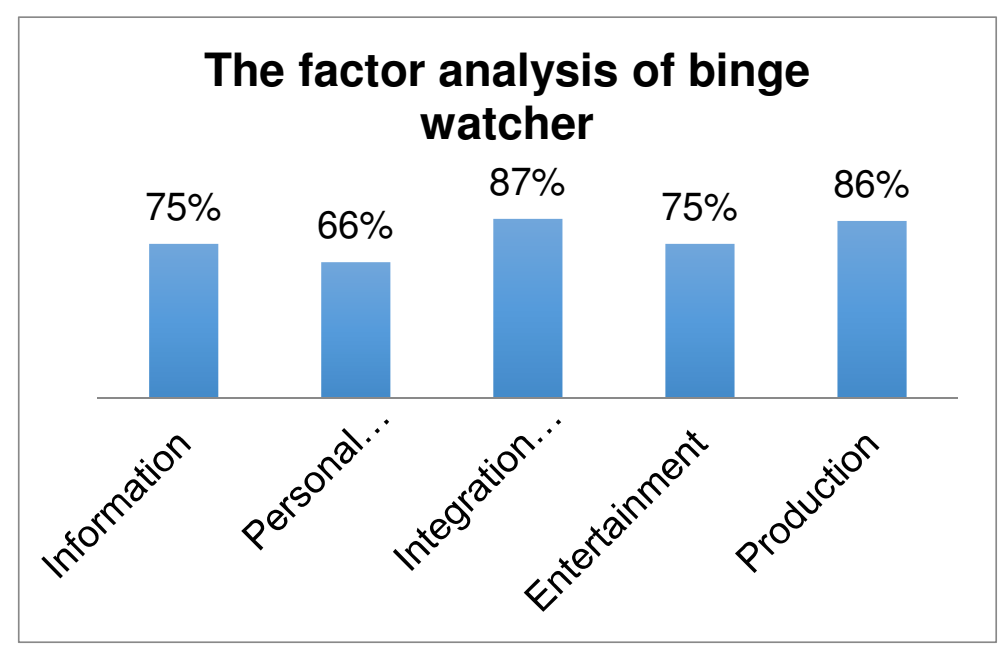

\section{Graph 6: The factor analysis of binge watcher in context of The Protector}

According to Graph 6, there is no positive correlation between being a binge watcher and the factors. Binge watchers mostly answered "indecisive" to questions related to factors in the survey. Binge watchers are indecisive by $75 \%$ according to information factor, $87 \%$ according to integration and social interaction factor, $66 \%$ according to personal identity factor, $86 \%$ according to production factor and $75 \%$ according to entertainment factor.

To the findings, \%49 of binge watchers stated "indecisive" to the statement "to avoid of spoiler" related to information factor. It is the highest neutral value among the answers of the questions related to information factor. \%72 of binge watchers is indecisive to the statement that's related to personal identity factor "Since I felt an identification with the star of the series I wanted to watch all the episodes one after another". It is the highest neutral value among the answers of the questions related to personal identity factor. $\% 76$ of binge watchers is indecisive to the statement that is related to integration and social interaction "I wanted to watch all episodes of the series one after another to catch up the friends' chats". It is the highest neutral value among the answers of the questions related to integration and social interaction factor.

$\% 62$ of the binge watchers is indecisive to the statement that is related to production factor "Since I have liked the visual effects of the series, I wanted to watch all episodes of the series one after another". It is the highest neutral value among the answers of the questions related to production factor.\%50 of binge watchers is indecisive to the statement that is related to entertainment factor "As a cultural activity, I wanted to watch all episodes of the series one after another". It is the highest neutral value among the answers of the questions related to entertainment factor.

\section{Conclusion}

In recent years online broadcasting has accelerated through online broadcasting platform Netflix. Therefore the generation $Z$ that defined as digital natives has a differenciaty viewing habit. It is defined as binge watch and binge racer by Netflix. The users watch episodes of a Netflix series at one time nonstop. The aim of the research is to find ut the factors carry out generation Z's online viewing habits, in the context of uses and gratification theory. To conduct the research The Protector, the first Turkish series of Netflix, is choosen as a case and survey is done with The Protector's watchers. 
According to findings of the research online viewing is quite common $(89,1)$ among the youngs who are between 18 and 24 in Turkey. It can say that almost 9 over 10 of the youngs are watching online series in the context of the universe of the research. As binge watchers' rate is \%96,4, binge racers' rate is $\% 67,3$ to the findings. This finding suggests that there is no or very low habit of watching television among young people in the specified age range. In order to have a final judgment, a research on the television viewing habits of this age range is needed.

The obtained data from the research on the first Turkish TV series The Protector broadcasted by Netflix, also supports the known data. To the sample of the research \%28 of them watched it as binge racer and $\% 65$ of them watched it as binge watcher. To the obtained data from the sample of the research \%28 of them watched it as binge racer and \%65 of them watched it as binge watcher. This finding verifies the conjecture "Watchers of the The Protector series are a binge racer or a binge watcher" in $\mathrm{H} 1$ and $\mathrm{H} 2$. On the other hand when that data compares to the general data about to be a binge racer or binge watcher, it is a little bit down.

There is a positive corelation between information, integration and social interaction, personal identity, entertainment and production factors and being a binge racer of the Protector in particular. On the other hand no corelation has found out between being a binge watcher and information, integration and social interaction, personal identity, entertainment and production factor. The factors affecting the binge watchers of the series have not been clearly identified. To the obtained data on entertainment factor, it can assume that binge watchers have seen the Protector to spend their free time.

To the findings of the research there is a positive corelation between factors and being a binge racer, so that $\mathrm{H} 3, \mathrm{H} 4, \mathrm{H} 5, \mathrm{H} 6$ and $\mathrm{H} 7$ is verified. On the other hand no corelation (positive or negative) has found out between the factors and being a binge watchers. It can conclude that binge racers are aware of their needs and they use media to gratify them but on the other hand it is not easy to say it for binge watchers.

In the context of the limitation of the study, while data related to being a binge racer can be accessed, no satisfactory data about being a binge watcher can be accessed. In this case, it is recommended that the research be repeated with other research methods such as observation, face to face interview, focus group and etc.

As a conclusion, we can say that the first Turkish series of Netflix The Protector is not liked to the low rate of binge racers of the series and no corelation between the factors and binge watchers. On the other hand to be a binge racer that's quite common in Gen Z coincides with the uses of media in the context of Uses and Gratification Theory.

\section{References}

[1] Büyüköztürk, Ş. (2002, Güz). Faktör Analizi: Temel Kavramlar ve Ölçek Geliştirmede Kullanımı. Kuram ve Uygulamada Eğitim Yönetimi Dergisi (s.470-483).

[2] Güngör, N. (2013). İletişim Kuramlar Yaklaşımlar. Ankara: Ekinoks Yayın Dağıtım.

[3] Krstić, S. (2018). "Binge-Watching": The New Way of Watching TV Series. AM Časopis za studije umetnosti i medija, 15-23.

[4] Lebo, Todd (2019). Hyper-Personalization: What It Is and Why You Need It in Your 2019

Marketing, Retrieved from https://www.convinceandconvert.com/research/hyperpersonalization

[5] Poe, M. T. (2014). Illetişim tarihi. İstanbul: Islık Yayınları.

[6] Seymen, A. F. (2017). Y ve Z Kuşak İnsanı Özelliklerinin Milli Eğitim Bakanlığı 2014-2019 Stratejik Programı ve TÜBiTAK Vizyon 2023 Öngörüleri ile İlişkilendirilmesi. Kent Kültürü ve Yönetimi , 467-489.

[7] Stillman, D. \& Stillman, J. (2017). İşte Z Kuşağı. İstanbul: IKÜ Yayınevi.

[8] Twenge, J. (2009). Ben Nesli. İstanbul: Kaknüs Yayınları.

[9] Tokgöz, O. (2015). İletişim Kuramlarına Anlam Vermek. Ankara: İmge Kitabevi

[10] Uzun, R. (2013). İzleyici Merkezli Yaklaşımlar. E. Yüksel içinde, İletişim Kuramları, Eskişehir: Anadolu Üniversitesi Yayınları.

DOI NO: 10.7456/ctc_2019_01

(C) İstanbul Aydın University 
[11] Yengin, D., \& Kınay, Ö. (2015). Yeni Medyada Boş Zamanın Dönüşümü: Tıkınmalı İzleme. D. Yengin içinde, Sosyal Medya Araştırmaları (s. 221-224). İstanbul: Paloma.

[12] www.media.netflix.com, 2019.

[13] "What does Croanbach's Alpha mean?", 2019, https://stats.idre.ucla.edu/spss/faq/what-doescronbachs-alpha-mean/,

[14] "Cronbach's Alpha: Simple Definition, Use and Interpretation", 2019, https://www.statisticshowto.datasciencecentral.com/cronbachs-alpha-spss/ 